\title{
Global politics and education systems: towards education markets?
}

\author{
Leoncio Vega Gil * \\ Dpto. Teoría e Historia de la Educación, Universidad de Salamanca, Spain \{lvg@usal.es\} \\ Received on 22 March 2013; revised on 29 March 2013; accepted on 10 May 2013; published on 15 July 2013 \\ DOI: 10.7821/naer.2.2.95-101
}

\begin{abstract}
Our paper has as its first aim to highlight the fact that the approach on which studies about educational policies or the politics of education (the second concept being more widely used in social sciences) have been based so far involves returning to the stance posited by J.A. Maravall -a category composed of ideas, foundations, mind-set, ideology, etc.; in other words, politics as an idea. A second analytical category would be expressed by norms, legislation, actions, practices, etc., which represent politics as regulation (Dutercq, 2005). Despite placing our study within the management of both categories from a methodological point of view, our focus is more specifically placed on the second interpretation. Thus, new education policies break the 'methodological nationalism' with a view to present standardized, mercantile and global discourses and practices as a demand of international education agencies. These global policies end, or begin, by building a social and practical network identified here as 'schooling market' and expressed through private ownership of schools and governance (the social use of education practices), which operates with different degrees of intensity across international education systems.
\end{abstract}

KEYWORDS: SOCIAL CONTEXT, GLOBALIZATION, EDUCATIONAL ADMINISTRATION, EDUCATIONAL POLICY, GOVERNANCE.

\section{SUBJECT TOPIC}

The multiple connections and dependences between global economic and cultural processes and their potential effects upon education (as a dependent variable) have been studied by scholars like Arnove (1999), Burbules (2001), Torres (2007), Carney, Reppleye, and Silova (2012), Dale (2007), Green and Janmaat (2011), Meyer and Ramírez (2010), Rizvi (2008) or Lingard and Rawolle (2010), at an international level; in Spain, approaches have been made by Aróstegui and Martínez (2008), Bonal, Tarabini-Castellani, and Verger (2007), Pereyra, Kotthoff, and Cowen (2011), Puelles (2009) and Fernández (2008). This paper attempts to research and/or analyze the paradoxical relationships that occur within the postmodernityglobalization-education triangle, a trilogy that operates within a systemic structure that we know as education (or school) systems. These connections are marked and/or determined by

\footnotetext{
*To whom correspondence should be addressed:

Facultad de Educación

Paseo de Canalejas, 169

37008 Salamanca

Spain
}

international bodies with an educational impact. To what extent is the conceptual, methodological and pedagogical agenda of education policies developed or marked by international bodies as educational players? And, should the answer be an affirmative one, what are the resulting educational scenarios?

\section{THEORETICAL FOUNDATION. POSTMODERNITY AND EDUCATION}

The cultural, intellectual and social debate on postmodernity started in the late 1970's and early 1980's. For a group of intellectuals (Lyotard, 1984; Derrida, 1998; or Foucault, 1970), postmodernity would be a rupture with the modernity which originated in the Enlightenment. This new era of culture and thought focuses on discontinuities, ruptures and cultural deconstructions, and therefore emphasizes diversity, sectoriality, specialization and flexibility; this is a social and cultural philosophy of a French nature (Gulevsky, 2012). Some authors suspect that there is a potential neoconservatism implicit in deconstructionist historiography and in those discourses based on the "end of history". In its application to the analysis of education policies, postmodernism focuses on the divergences among educational discourses, players and processes, rather than on converging elements. The postmodernist praise of plurality, difference and multiple narratives must face what some authors have termed the "restrictive implications" it may have for change, social justice and democracy (Olssen, Codd, \& O'Neill, 2004). The irony of postmodernism lies on what is not recognized and what is not challenged. In other words, "a theorization mode, originally concerned with giving a voice to silent minorities, eventually suppresses social differences towards a totalizing discourse whose result is nothing but an alienated form of subjectivity" (Welch, 2002, our translation). The difference, far from being an empirical fact, has been reduced to an abstraction, to a formal category. The postmodernist atomism removes individuals from their institutional contexts. From a moral perspective, Welch advocates a return to certain values of modernity, and a refusal of the moral nihilism of postmodernity (2002).

Another group of intellectuals (Habermas, 2008; Beck, Giddens, \& Lash, 1994) hold a different view of our culture. Postmodernity would rather be synonymous with antimodernity (Habermas, 2008), an emotional stance which is part of postEnlightenment. For Giddens (2007), the postmodern order has not yet started, and the current situation would be part of the "high modernity", a period when modern trends become radical and universal. Many of the so-called postmodern developments would actually be modern forms which are historically 
unknown, but not the expression of fragmentations, dissolutions or ruptures. Change and continuity would be an inseparable component of cultural processes and practices. From this second notion of postmodernity, education will be expressed through new trends which ensure the continuity of the modern project. Educational policy (currently under development as a discipline) has been subject to external influences (probably not as much as would be desirable because, like other pedagogical disciplines, it has moved somewhat away from social sciences) which have resulted on an emphasis on diversity, pluralism and interculturality; the introduction of new teaching and research topics (gender, children's rights, inclusión, development, interculturality, etc.), which may be interpreted as evidence of deconstructive fragmentation; attention towards issues related to "high modernity", such as case studies, individuality, solidarity, singularities and social justice. A return to the subject and to players, as opposed to an analysis of structures. In other words, the theoretical reference framework would be expressed through a "theoretical relativism".

\section{THE RESULTS. GLOBALIZATION, EDUCATION AND GOVERNANCE}

The narrative origin of globalization may be traced back to the 1970's (Burbules \& Torres, 2001), which means that its intellectual and cultural development runs parallel to the discourse of postmodernity. However, in the 21st century political, sociological, economic and pedagogical discourse focuses on the term "globalization", an expression which is close to other labels like "postfordism" (or neofordism), "postindustrialism", "informational society" from a sociological perspective, or the term "multiple modernities" from a cultural perspective (the de-Westernisation of our view of modernity) (Sachsenmaier, 2010). All of these emphasize economics and politics, that is, the change in the structural paradigm according to which the global scenario is dominated by services, whereas manufacturing industries have ceased to be the key factor in the economy. In this respect, neoliberalism and globalization would be synonymous terms, and their institutional expressions are embodied in the "neoliberal alibi" (Aróstegui \& Martínez, 2008), decentralization and accountability. How must globalization be interpreted in connection with postmodernity? It is a product, an expression, an indicator, a reading, a disease according to Harvey (Rizvi, 2008), an ideology (Gimeno, 2001), etc.; probably each and every one of them, but also a set of acts and processes which combine each of these expressions. Nevertheless, such economic and political view of globalization has its social (the antiglobalization movements) and intellectual opponents (Sousa, 2005). For this Portuguese sociologist, another world is possible, and so is another social theory. His argumentation is based on notions which include "counterhegemonic democracy" (reinventing democracy) (Aguiló, 2009), "monocultures", "sociology of absences", "ecology of the different knowledges" and "counter-hegemonic globalization", amongst others. This latter notion, as applied to the organization of universities, requires three types of reforms: public universities as the key players; a reorganization of the nationstate so that it may develop "solidarious globalization", and thirdly, citizens (participation) and social movements.

Rizvi (2008) lists a number of contributions by thinkers (mainly philosophers and sociologists) who argue that global processes are alien to the cultural and educational area. However, "it is impossible that globalization may have no effect upon educational research theories and methodologies" (Bonal, Tarabani \& Verger, 2007) and it may neither be separated from teaching practices; globalization and its consequences are a social and ideological "problem" for educational policy (Puelles, 2006). One thing is that there may be a "paradigm shift" (as is the case in the economic sphere), and quite another is that there are no effects or consequences. From this second point of view, we shall consider and analyse now three main areas of influence. On the one hand, the changes in the educational and research agenda deriving from the studies, meetings, programmes and proposals from international bodies (educational multilateralism). The OECD has recently eliminated equity from its research agenda at the individual request of its member states, as a result of the economic crisis. International bodies have become the international educational players par excellence by determining the relationship between global processes and the national educational policies acting upon education systems (globalization and comparison). The nation-state is not withdrawing, but rather has suffered some changes; it continues to play the role of providing, regulating and coordinating. The present economic crisis and the measures adopted in order to overcome it, have eventually confirmed Dale's theses, according to which globalization has not made nation-states something obsolete and irrelevant (2007). The "relative confirmation" refers to the fact that States do intervene through public expenditure and a greater regulation of financial processes, but at the same time such agreements are coordinated with other states or with international bodies. Then, we shall deal with the influence of global policies on education systems and global education (Arnove, 1999). Finally, our study will conclude with an analysis of the educational networks known as "education markets" (or rather, "schooling markets", in order to be more precise from an institutional point of view) and their reflection on pedagogical policies and practices.

\subsection{International bodies and the political- educational agenda}

The studies on the influence of international bodies on (national and international) educational agendas (educational multilateralism, as defined by Mundy 2007) have been based on three main ideas: the problems in international education stem from the structure and management of these bodies; these international bodies are instruments of Western neoimperialism (the neomarxist thesis, quite prevalent in some contexts, like Latin America), and the role of these bodies in the shaping of a world culture which is characterized by homogeneous national educational policies, linked to modern notions of the nation and the citizen. However, these views do not consider the various forms of educational multilateralism, nor the changes (both methodological and strategic) which occur within international bodies with the passage of time and experience. In this respect, attention should be paid to Mundy's (2007) notions of "redistributive multilateralism" and "defensive and disciplinary multilateralism".

In the 1980's, defensive and disciplinary multilateralism (expressed through the monetarist, neoliberal, neoconservative and tax approaches) advocates the limitation of state intervention and an emphasis on the free global market, a product of the Reaganist and Thatcherite policies which fought to separate the state from the social forces of company behaviour. Mundy (2007) focuses on three forms of educational multilateralism in the late 20th century. On the one hand, a dramatic reduction in resources allocated to development (USA, UK and other OECD 
countries) affecting education, although paradoxically there is an increase in loans by the World Bank. A clear example is what happened to UNESCO, with the withdrawal of countries like the United States, United Kingdom or Singapore, who opposed the demands by Third World countries. Also the UNDP education budget was reduced. In the 1990's, the educational work recovered some strength because these bodies looked North (World Education for All Conference, literacy as a global problem, or the publication of world reports). Secondly, the forms adopted by defensive and disciplinary educational multilateralism. As developed countries ceased to support redistributive multilateralism, they became more and more involved in other forms of multilateralism (defensive multilateralism) that left developing countries to their own devices. This educational "defence" leads to a reinforcement of the national educational sectors in order to become more competitive in the international economic sphere. It is "disciplinary" because it imposes neoliberalism in public policies coming from the United States and the United Kingdom.

A clear expression of this multilateral shift is the OECD, which has displaced UNESCO as the central focus of political coordination among developed countries. The standards, quality indicators, international competencies assessments (for young people and adults), the international statistics and studies (like the 2005 teacher evaluation, on which the UNESCO 2007 study is based) and the focus on lifelong learning have become the political-educational reference for the North and the educational multilateralism for the South. The OECD has attributed itself the role of key player in the field of educational policy, through initiatives like the establishment of an international agenda, the formulation of international policies, and the coordination of such policies. Historically, the OECD had been a forum for the free exchange of ideas in the educational area, but it has become a neoliberalism-dominated political player in the international management of education.

The NAFTA or the European Union are also part of such defensive multilateralism. The European Union, as an international body, focused the European approach to educational cooperation on exchange and mobility in the 1980's. However, starting from the 1990's, mention and emphasis must be made on the "subsidiary" effort towards the European education area (Lawn \& Novoa, 2005), the society of knowledge, the Europe of training and employment and the EHEA. And thirdly, education for all (EFA) and the (neoliberal) reorganization of educational aid.

The rise of neoliberalism had a paradoxical impact on educational aid. On the one hand, it led, as we have mentioned, to restrictions and cuts (UNESCO, UNO, UNDP, OECD, etc.), and on the other, it also led to the creation of new mechanisms for the implementation of internal educational policies through the World Bank (WB). Unicef and the UNDP played a leading role in that "pressure" exerted on the WB so that it returned to the basic needs approaches (whereby primary education becomes the great political priority, through the Fast Track initiative) and abandoned the structural cuts policy, which only lead to greater poverty and need.

Finally, it is necessary to mention, as part of the multilateral effort supported by supranational bodies, that made by the World Education for All Conference, under the auspices of Unicef, which was joined by UNESCO and the WB. However, in spite of the efforts by the WB to lead the EFA agenda, this institution still suffers from contradictions (both ideological and practical), because it continues to emphasize the economic results of education (the school on education), it adopts a topdown approach (experts), it creates unrest among the EFA partners (some of them still cling to the redistributive development alternatives of the 1970's), the efforts to join a neoliberal loan policy with an focus on a greater legitimacy as a world mediator for global welfare (the "advocate for the poor"); also, Latin America has criticized its "Africanization". On the other hand, the world "bank" should be replaced, and a new name should be chosen, such as OWD (Organization for World Development). The educational policy could be decided within the United Nations, giving more weight to UNESCO (an option which is rejected by some, because decisions at UNESCO are made by education ministers, and therefore financial restrictions are not present), or by a joint authority which required the consent of the two institutions.

Therefore, international bodies are placed between global processes and education systems, as mediators which direct, control and supervise educational processes and re-orient the actions of nation-states.

\subsection{Globalization and education systems}

During the 1990's studies on educational policy gained new strength. In our opinion, this renewed interest in educational policies could be due to two types of factors: external and internal ones. Concerning the former, there is the impact of globalization phenomena and the desire to evaluate national systems through international scales and criteria, and the development of the European Union as a plural political framework where education becomes a focus of interest and regulation. At an internal level, the variables to be considered have to do with regional diversity, equality policies and reforming the curriculum for social educators, teachers and pedagogists.

In principle, globalization and education policy seem irreconcilable given their different character and nature. Globalization involves overcoming the nation-state and world homogeneization, whereas education policy prioritizes education systems, and such systems pertain to the nation-state, which establishes and directs them: it is, therefore, an individualization (Vega, 2011b). However, (2002) argues that globalization is not a threat for education systems, because the nation-state has changed (it has not disappeared), and it had never enjoyed so much autonomy. In other words, globalization may require an economic paradigm shift, but not necessarily a shift in educational policies. This paradigm shift does not mean that the world system will be less "state-based", or that education systems will be separated from the state. Neither does globalization lead necessarily towards homogeneization: there are no reasons to believe that diversity will suffer. Globalization needs the states, and states are founded on, and disseminated by, education systems.

However, it is possible that there is a certain crisis in educational policy as a consequence of globalization, educational transfer and the defensive reaction of nation-states. The readjustments or reductions in studies on international educational policies and reforms in the United States, Great Britain, Germany or Australia have been accompanied by a connection between international development and national topics (Welch, 2002), mainly due to the PISA assessments. However, such "reductions", like those occurring in Hong Kong, Latin America or Spain, do not occur in all contexts. In any case, 
this would be a re-orientation from traditional pedagogical areas towards new lines of teaching and research (education and development; environmental pedagogy; gender and education; lifelong learning; childhood rights; Naya \& Dávila, 2005).

"Global" processes and policies are directly connected to the "world education systems", because in country studies the functionality and singularity of education systems is usually exaggerated, and little attention is paid by many of the educational similarities between countries (Meyer \& Ramírez, 2010). These authors analyse the notion of "global standardization of education"; such standardization affects, first, the nation-state, and is explained by factors like the fact that the world is more and more integrated, that the normative model is becoming standardized, rights, citizens and education have become institutionalized through international bodies. Secondly, it affects education, insofar as "world models" are increasingly defended through international bodies in educational terms. The dimensions of the global standardization of education are expressed through components of education systems, such as the basic education structure; contents and teaching; educational organization; internationalization; isomorphism and glocalization (Meyer \& Ramírez, 2010).

The same interpretation may be given to the latest work by Rizvi and Lingard (2010), who argue that educational policies have been affected by economic, social and political changes, and that national governments have attempted to realign their educational priorities towards what they perceive as the global imperatives (the neoliberal imaginary), as determined by international bodies. We would like to make four considerations on this book. Firstly, the "critical approach" taken by the authors, which leads to a discourse analysing the concepts, interpretations and developments (political, institutional and/or academic ones regarding programmes), which then confronts them with other discourses, values or principles affecting social cohesion, personal security and the democratization of education and culture. A second axis of their discourse is the confidence in, and the defence of, the nation-state as the protector of public policies leading to the theses by Stiglitz (2002) and Giddens (1999 and 2007) of the "third way" (combining the State and the market) as a way to re-orient the "individualization" and "depolitization" of new public management (NPM) as the institutional embodiment of neoliberal globalization. This third way would be the bequest of globalization (Holmes, 2009). In an explicit reference to the OECD, the "depolitization of educational issues leads the organization to reconceptualize its policy work in mostly technical terms" (Rizvi \& Lingard, 2010, p. 131) or the "data policy". A third contribution of this work is that it specifies the topics which make up the education globalization agenda: after analysing the interpretations of globalization (and the intellectual positions on this phenomenon), the study focuses on topics like the prevailing or underlying values in policy actions; the curriculum and its assessment processes; public policy management ("from government to governance"); educational policies and equity; mobility and international academic flows (and their "languages") and the protests and reactions against this "economic" interpretation of globalization. Fourthly, the book finishes with a chapter which "rethinks" or "reimagines" other globalizations, with analyses on how to "tame" globalization, given that, as Stiglitz has pointed out, neoliberal globalization has led to "democratic deficit" caused by international organizations (Rizvi \& Lingard, 2010, p. 190), possible alternatives and how to reorient the "neoliberal imaginary" by reconceptualising the values of efficiency, equity, community, freedom and security as foundations of public policies.

Given that the markets and the presence of society in educational bodies, programmes and policies include, in most cases, a new approach or analysis of such bodies, programmes and policies from the (ideological) interpretations of quality, we consider that this discourse lies outside our approach, as it considers the analysis from a way of interpreting governance. Not because we do not believe it interesting in its various expressions, manipulations and interpretations (Puelles, 2009), but because we think it is included in the policies and practices towards "school networks" and because, from this perspective, an evolution has occurred towards excellence, benchmarking, standards and competition (the neoliberal narrative) (Aróstegui \& Martínez, 2008).

\subsection{Towards the markets of education and governance}

Pérez and Gorga (2008) have related the contemporary schools of thought on mundialization by Held and McGrew (2007) (global sceptics and community-cosmopolitans) with the potential educational scenarios proposed by the OECD in its programme "Schooling for Tomorrow" (2001).

Table 1. Educational scenarios and global thought

\begin{tabular}{cc}
\hline Poles & Thought \\
\hline Extrapolating the status quo & Sceptics \\
\hline Re-schooling & Eeformists \\
\hline De-schooling & Hiperglobalists \\
\hline
\end{tabular}

The last scenario corresponds to the "extension of the market model", where education is interpreted as a commodity, a consumer item. This typology is not only interesting because of its relationship with "schools", but also because it indicates that there are different ways of analizing mundialization and its impacts on national and local societies. Also, it informs us that mundialization is a complex, dynamic concept, which leads to different stances depending on the analysis perspectives and the cultural and scientific tradition of researchers (Pérez \& Gorga, 2008, p. 57).

According to Dale (2007), the effects of "economic globalization" on education may be grouped into three categories: direct effects (voluntary and predictable), affecting mostly higher education, and embodied in the "education market"; indirect effect (involuntary and predictable), such as the business of competence in English, the "global language" and "macdonaldization"; and thirdly, the collateral effect, such as the cultural and educational effects provoked by migration processes, and also the new relationships between human capital and the division of work (the economy of knowledge), which requires a new approach to educational policies and practices.

Torres (2007) proposes a categorization of the mercantilization of education systems in four dimensions:

a) the decentralization of the systems, expressed through the delegation of powers and roles; deregulation, which removes all protection for those most in need; dezoning (when choosing the school), although it might be more appropriate to speak about "rezoning", because neoliberal policies are expanding the geographical zones by reducing their total numbers, which widens the choice of school because the zone coincides with local councils, 
as has been the case in Spanish regions like Madrid or Castile-Leon; and competition among schools;

b) credentialism and competitive excellence (expressed through practices, programmes and centres of excellence);

c) the naturalization of the individual component (the culture of personal effort and individual intervention policies);

d) it would be defined by privatization.

From our analytical point of view, this latter category is the prevailing one in the mercantilization of education. In our opinion, this privatization acts in five ways:

- ownership (private ownership of educational centres);

- educational institutions contracting services with privately-owned agencies or companies;

- the individualization of educational and training processes through ICTs;

— the "parallel" education system, which is embodied in complementary actions such as private lessons, reinforcement lessons, after-school activities and other practices;

- what we could call "the social dimension of pedagogical processes".

This latter form deserves more attention because it narrows down the notion of "governance", which we interpret as privatization, and not only as management or governability (Vega, 2011a). When pedagogical practices of evaluation, selection, control, supervision, provision, management, setting standards, etc. which are practices determined by policies, are expressed through marketing, the media, noticeboards and other social media, acquire not only a "pedagogical" dimension, but also a social and competitive (global) one.

Lundströn and Holm (2011) have studied how this network operates in the practices of educational players in higher secondary education in Sweden; Mansell (2007) studies the case of Great Britain (focusing on the "tyranny of empirical testing"). For his part, Felouzis (2011) considers the education systems of countries like Belgium, Great Britain, South Africa, the United States, Switzerland and France, on the one hand, in order to explain the different theoretical approaches to the "schooling markets", and on the other, in order to offer us an interpretation pattern combining policies, practices and forms of expression of these global networks.

Tabla 2. Formas de regulación de los mercados escolares

\begin{tabular}{ccccc}
\hline $\begin{array}{c}\text { Empirical } \\
\text { dimension }\end{array}$ & Players & $\begin{array}{c}\text { Guiding } \\
\text { logic }\end{array}$ & Regulation & $\begin{array}{c}\text { Form of } \\
\text { expression }\end{array}$ \\
\hline $\begin{array}{c}\text { Choice of } \\
\text { school }\end{array}$ & Family & Demand & $\begin{array}{c}\text { Educational } \\
\text { quality }\end{array}$ & $\begin{array}{c}\text { Singularities } \\
\text { market }\end{array}$ \\
\hline $\begin{array}{c}\text { Educational } \\
\text { policies }\end{array}$ & $\begin{array}{c}\text { State/ } \\
\text { region }\end{array}$ & $\begin{array}{c}\text { Post- } \\
\text { bureaucracy }\end{array}$ & $\begin{array}{c}\text { Quality } \\
\text { assessment }\end{array}$ & Quasi-market \\
\hline $\begin{array}{c}\text { Competition } \\
\text { among } \\
\text { schools }\end{array}$ & $\begin{array}{c}\text { Head- } \\
\text { masters }\end{array}$ & Offer & $\begin{array}{c}\text { Local } \\
\text { competition } \\
\text { according } \\
\text { to quality }\end{array}$ & $\begin{array}{c}\text { Competitive } \\
\text { interrelation- } \\
\text { ships }\end{array}$ \\
\hline
\end{tabular}

Following the analytical logic of our approach, we shall now make an explanatory effort in order to represent the policies and practices through which these networks operate, concentrating on two variables: the private ownership of educational centres and the governance (the social and competitive dimension of educational practices and processes). Both applied to the 14 education systems whose selection we have already argued and explained elsewhere (Vega 2011b); all of them considered as a teaching object, both of Educational Policy and of Comparative Education.

Ownership is expressed through the percentage of 15-year-old students attending private schools (both independent or with public funding). A+ Governance indicates a positive statistical relationship between the social use of assessments and accountability and the acquisition of skills, considering the social and economic context. M+ shows the education systems where the relationship between the social use of educational practices and performance is a positive one, without considering the social and economic context.

The next table yields three projections. Firstly, systems with a high percentage of schooling in private centres are not always those where there is a direct, positive relationship with a greater social use of pedagogical practices. Secondly, the education systems regulated by a "quasi-market" do apply policies of social regulation of pedagogical practices. Thirdly, "regional", "local" and "centralized" education systems are not as prone to neoliberal policies as the previous ones.

\section{CONCLUSIONS}

This final section should have a threefold dimension. The effects of globalization on education systems, the convergences of "global education", and thirdly, the new mercantile networks in

Table 3. Education systems and governance

\begin{tabular}{|c|c|c|c|c|c|c|}
\hline \multirow[b]{2}{*}{ Country/System } & \multirow[b]{2}{*}{ Mode of regulation } & \multicolumn{3}{|c|}{ Ownership } & \multicolumn{2}{|c|}{ Governance } \\
\hline & & High (\%) & Medium (\%) & Low (\%) & High & Low \\
\hline Australia & Quasi-market & & 39 & & + & + \\
\hline Canada & Regional & & & 5 & & \\
\hline Chile & Quasi-market & & 51 & & & + \\
\hline Finland & Local & & & 4 & & \\
\hline France & Centralized & & & - & & \\
\hline Germany & Regional & & & 4 & & + \\
\hline Hong-Kong & Asian & 92 & & & + & + \\
\hline Ireland & Local & 57 & & & & \\
\hline Japan & Asian & & 29 & & + & + \\
\hline Korea & Asian & & 35 & & & \\
\hline Netherlands & Quasi-market & 64 & & & & + \\
\hline Sweden & Local & & & 10 & + & \\
\hline United Kingdom & Quasi-market & & & 5 & + & \\
\hline United States & Quasi-market & & & 8 & + & + \\
\hline
\end{tabular}


education. The first category is embodied by the acceleration of the decentralization process, and their consequence, "institutional autonomy"; in the "community dilemma" and governance (there is a demand for schools to have a greater social dimension, but at the same time there is a mistrust and a criticism of the relationships between schools and the social community; also, we are witnessing processes with a higher "privatization", both in terms of individualization and in terms of allocation of services to social initiative and the mercantilization of educational spaces); decentralization (also paradoxical) leads to a greater control, which is exerted from the processes evaluating the systems, the schools and the teaching profession (although, quite contradictorily, the strong resistance of teachers in some contexts is so far leaving the profession somewhat outside this control) through scales following criteria set by international organizations; the society of knowledge, or rather, the societies of knowledge, are marked by the growing presence of migration flows in school spaces and demand new relationships (both structural and methodological ones); and the educational multilateralism (both defensive and disciplinary), which shows that international bodies have placed themselves as "mediators" between global processes (economic, cultural and social ones) and the organization and the way education systems are organized and work.

The second category is expressed through "global education", which is embodied in the "world standardization of education"”, (Meyer \& Ramírez, 2010) (the language, mathematics and science curriculum; the institutional organization of education; the formal schooling practice model, or the role of the teacher more as an educator than as an instructor; that is, the global educational forms) and the global convergence of education (Rizvi, 2010) through the movement of ideas (supported by mobility and exchanges), consensus (the Bologna process in the European Union), competence and education (in higher education; corporate universities) and the agreements and "dependences" of developing countries, on which requirements are made to adjust and restructure their education systems.

The global educational policies are expressed both at a macrolevel and at a microlevel. At a macrolevel, education systems are increasingly sharing forms of organization, curricular design, academic structures and forms of government; morphologically all education systems are basically "the same". But at a microlevel, also the behaviour of institutional players (students, teachers and managers) shows increasingly common practices and processes (teaching methodologies, evaluation systems, conflict resolution systems, etc.). One of the most controversial and representative expressions of global educational policies is the evaluation according to standardized criteria defined by international skill assessment programmes. An evaluation (a paradoxical one) acting at various levels (systems: accountability; schools: adaptation to the medium; managers: autonomy; teachers: performance; and students: skills). However, evaluation is only a political, pedagogical practice measuring the acquisition of knowledge. But it is raised to the category of governance (social and mercantile usage) when it goes beyond the classroom and the school and it becomes the tool for the social legitimation of the choice of school, of quality, of segregation, of management and excellence; in other words, it is used towards the competitiveness and the privatization of policies and practices in the internal dynamics of public educational process (and with a greater emphasis in privately-owned schools)

\section{REFERENCES}

Aguiló, A. J. (2009). La democracia contrahegemónica en la teoría política de Boaventura de Sousa Santos: notas sobre un proyecto emancipador para el siglo XXI. Presente, pasado y futuro de la democracia, 377-383. Retrieved from http://congresos.um.es/sefp2009/paper/viewfile/3511/3761

Arnove, R. (1999). Reframing comparative education: the dialectic of the global and the local. In F. F. Arnove \& C. A. Torres (Eds.), Comparative education. The dialectic of the global and the local (pp. 124). Oxford: Rowman \& Littlefield Publishers.

Aróstegui, J.L. \& Martínez, J.B. (2008).Globalización, posmodernidad y educación. La calidad como coartada neoliberal. Madrid: Akal.

Beck, U., Giddens, A., \& Lash, S. (1994). Reflexive modernization: Politics, Tradition and Aesthetics in the Modern Social Order. California: Stanford University Press.

Bonal, L.X, Tarabini-Castellani, A., \& Verger, A. (Comps.) (2007). Globalización y educación. Textos fundamentales. Buenos Aires: Miño y Dávila.

Burbules, N.C. \& Torres, C.A. (2001). Globalización y educación. Revista de Educación(Madrid), no.extraordinario 2001, 13-29.

Carney, S., Reppleye, J., \& Silova, I. (2012). Between Faith and Science: World Culture Theory and Comparative Education. Comparative Education Review, 56(3), 366-393. doi: 10.1086/665708

Dale, R. (2002). Globalización: ¿un nuevo mundo para la educación comparada? In J. Schriewer (Comp.), Formación del discurso en la educación comparada (69-88). Barcelona: Ediciones Pomares.

Dale, R. (2007). Los efectos de la globalización en la política educativa nacional. Un análisis de los mecanismos. In X. Bonal et al. (Comps.), Globalización y educación. Textos fundamentales (87-114). Buenos Aires: Miño y Dávila.

Derrida, J. (1998). Márgenes de la filosofia. Madrid: Cátedra.

Dutercq, Y. (2005). Les régulations des politiques d'éducation. Rennes: Presses Universitaires de Rennes.

Felouzis, G. (2011). Les marchés scolaires et l'éducation comparée. Éducation Comparée, 6, 7-27.

Fernández, J. M. (2008). Derecho a la educación y libertad de enseñanza en la reforma educativa (LOE). Revista de Educación (Madrid), 346, 245-266.

Foucault, M. (1970). La arqueología del saber. México: Siglo XXI.

Giddens, A. (1999). La tercera vía: la renovación de la socialdemocracia. Madrid: Taurus

Giddens, A. (2007). Europa en la era global. Barcelona: Paidós.

Gimeno, J. (2001). El significado y la función de la educación en la sociedad y cultura globalizadas. Revista de Educación (Madrid), $n^{o}$.extraordinario 2001, 121-142.

Green, A. \& Janmaat, J.G. (2011). Regimens of Social Cohesion: Societies and the Crisis of Globalization. Basingstoke: Pelgrave Macmillan. doi: 10.1057/9780230308633

Gulevsky-Obolonsky, G. (2012). Le postmodernisme: une réalité socioculturelle française. Retrieved from http://www.academia.edu/1786306/Le postmodernisme une realite _socioculturelle_francaise

Habermas, H. (2008). El discurso filosófico de la modernidad. Madrid: Katz Editores.

Held, D. \& McGrew, A. (2007). Globalization/Anti-Globalization. Beyond the Great Divide. Cambridge: Polity Press.

Holmes, A. R. (2009). The third way: globalization's legacy. Licester: Matado.

Lawn, M. \& Novoa, A. (2005). L'Europe réinventée. Regards critiques sur l'espace européen de l'éducation. Paris: L'Harmattan.

Lingard, B. \& Rawolle, S. (2010). Globalization and the Rescaling of Education Politics and Policy. In M. A. Larsen (Ed.), New Thinking in Comparative Education. Honouring Robert Cowen (33-52). Rotterdam: Sense Publishers.

Lyotard, J. F. (1984). The Postmodern Condition: A Report on Knowledge. Manchester: Mancherster University Press.

Lundströn, U. \& Holm, A. (2011). Market competition in upper secondary education: perceived effects on teachers 'work. Policiy Futures in Education, 9(2), 193-205. doi: 10.2304/pfie.2011.9.2.193

Mansell, W. (2007). Education by numbers: The Tyranny of Testing. Michigan: Politico's.

Meyer, J. W. \& Ramírez, F. O. (2010). La educación en la sociedad mundial. Teoría institucional y agenda de investigación de los sistemas educativos contemporáneos. Barcelona: Octaedro.

Mundy, K. (2007). El multilateralismo educativo y el (des)orden mundial. In X. Bonal, A. Tarabini-Castellani, \& A. Verger (Comps.), 
Globalización y educación. Textos fundamentales (pp. 117-161). Buenos Aires: Miño y Dávila.

Naya, L. M. \& Dávila, P. (2005). Los derechos de la infancia como objeto de la educación comparada: perspectivas e indicadores. In M. A. Pereyra (Ed.), Convergencias de la Educación Superior en el ámbito europeo y latinoamericano (pp. 639-660). Granada: Grupo Editorial Universitario. CD-ROM.

OCDE (2001). L'école de demain. Quel avenir pour nos écoles? París: OCDE.

OCDE (2010). PISA 2009 Results: What Make a School Successful? Resources, Policies and Practices. Vol. IV.

Olssen, M., Codd, J., \& O'Neill, A.M. (2004). Education Policy. Globalization, Citizenship and Democracy. London: SAGE Publication Ltd.

Pérez, S. \& Gorga, A (2008). L'éducation comparée á 1 'épocque de la mondialization. In S. Hanhart, A. Gorga, M. A. Broyton, \& T. Ogay, De la comparaison en éducation. Hommage á Soledad Pérez (pp. 5278). París: L'Harmattan.

Pereyra, M., Kotthoff, H.G., \& Cowen, R. (2011). PISA Under Examination. Changing Knowledge, Changing Tests, and Changing Schools. Rotterdam: Sense Publishers. doi: 10.2753/EUE1056-4934430406

Puelles, M. de (2006). Problemas actuales de politica educativa. Madrid: Morata.

Puelles, M. de (2009).Calidad, reformas escolares y equidad social. In M. A. Santos (Ed.), Politicas educativas y compromiso social (pp. 25-39). Barcelona: Octaedro.

Rizvi, F. (2008). La globalización y las políticas en materia de reforma educativa. In J. L. Aróstegue \& J. B. Martínez (Coords.), Globalización, posmodernidad y educación. La calidad como coartada neoliberal (pp. 91-120). Madrid: Akal.

Rizvi, F. \& Lingard, B. (2010). Globalizing education policy. N. York: Routledge.

Sachsenmaier, D. (2010). El concepto de modernidades múltiples y sus áreas adyacentes. In J. Schriewer \& H. Kaelbe (Comps.), La comparación en las ciencias sociales e históricas (pp. 109-136). Barcelona: Octaedro.

Sousa, B. de (2005). La universidad en el siglo XXI. Para una reforma democrática y emancipadora de la universidad. Retrieved from: http://bibliotecavirtual.clacso.org/or/libros/bolivia/cides/umbrales/15/ de_Sousa_SANTOS.pdf

Stiglitz, J. E. (2002). Globalization and its discontents. New York: Norton \& Company.

Torres, J. (2007). Educación en tiempos de neoliberalismo. Madrid: Morata.

Torres, C. A. (2009). Education and Neoliberal Globalization. New York: Routlegde.

Vega, L. (Ed.) (2011a).Gobernanza y políticas de formación de profesores en la Europa Mediterránea. Valencia: Tirant lo Blanch.

Vega, L. (2011b). La educación comparada e internacional. Procesos históricos y dinámicas globales. Barcelona: Octaedro. 